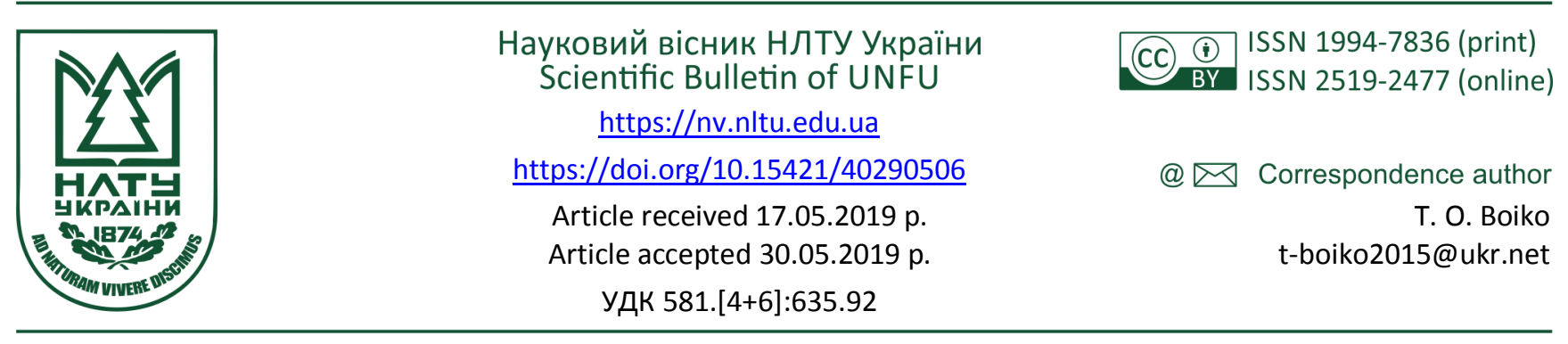

Т. О. Бойко, О. І. Дементьєва, Ю. С. Котовська

Херсонський державний аграрний університет, м. Херсон, Украӥна

\title{
ОЦІНЮВАННЯ БІОЛОГО-ЕКОЛОГІЧНИХ ВЛАСТИВОСТЕЙ ДЕРЕВНИХ ЛІАН В УМОВАХ МICТА ХЕРСОН
}

\begin{abstract}
У ході досліджень на території Херсона виявлено 31 вид деревних витких рослин. Встановлено, що всі деревні ліани, що використовуються в озелененні міста, $€$ інтродуцентами. Показниками їх успішного зростання та онтогенезу у нових умовах є зимостійкість, посухостійкість, стійкість до шкідників та хвороб, а також здатність до розмноження. Найбільш зимостійкими ліанами в досліджених умовах виявились Parthenocissus quinquefolia (L.) Planch., P. tricuspidata (Siebold \& Zucc.) Planch., Lonicera caprifolium L., Campsis radicans (L.) Seem., Actinidia kolomikta (Rupr.) Maxim. тa Clematis jackmanii Moore. Найвищий бал посухостійкості присвоєний тільки Fallopia baldshuanica (Regel) Holub та Wisteria sinensis (Sims) Sweet. Iнші види менш посухостійкі. Важливим чинником, який впливає на хід інтродукції, є стійкість до хвороб та шкідників. Виявлено, що найбільш стійкими є Celastrus scandens L., Lonicera periclymenum L., L. brownii (Reg.) Carr., L. japonica Thunb., Menispermum canadense L., Schisandra chinensis (Turcz.) Baill., Wisteria sinensis (Sims) Sweet. Рясно самосів утворюють Wisteria sinensis, Periploca graeca L., Ampelopsis aconitifolia Bge, Clematis manschurica Rupr., C. glauka Willd. Інші виткі рослини частіше розмножуються вегетативним шляхом. За результатами визначення коефіцієнта адаптації деревних ліан з'ясовано, що за комплексом ознак найбільш пристосовані до умов дослідження Ampelopsis aconitifolia, Campsis radicans, Celastrus orbiculata Thunb., Clematis jackmanii, Parthenocissus quinquefolia, P. tricuspidata, Lonicera caprifolium, L. giraldii Rehd., Fallopia baldshuanica (Regel) Holub, F. auberti (Henry) Holub, Menispermum canadense, Wisteria sinensis, Periploca graeca. Інші види $\epsilon$ обмежено перспективними або малоперспективними для вертикального озеленення міста, однак їх використання можливе при ретельному підборі місця посадки та організації догляду за ними.
\end{abstract}

Ключові слова: вертикальне озеленення; зимостійкість; посухостійкість; адаптація.

Вступ. Сучасні міста, зазвичай, мають екстенсивний тип розвитку, зумовлений соціально-економічними причинами. Для компенсації постійного погіршення умов у міському середовищі та населених пунктах потрібно, щоб система озеленення була максимально різноманітною за своїм складом і виконувала санітарно-захисні функції (Bagatska, 2008). Виткі рослини мають важливе естетичне, господарсько-економічне та санітарно-гігієнічне значення, але до сьогодні їм не приділялося достатньої уваги в озелененні Херсона, у насадженнях загального та спеціального призначення вони практично відсутні, частіше трапляються в приватному озелененні. 3 огляду на це асортимент деревних ліан не має загальної оцінки їх використання. Обгрунтоване застосування елементів вертикального озеленення дасть змогу підвищити естетичну і рекреаційну функції території, поліпшить якісні показники середовища.

Щільність забудови в деяких районах міста перешкоджає широкому впровадженню зелених насаджень, але водночас створює широкі можливості для використання витких рослин на вертикальних поверхнях буді- вель, споруд та огорож. Вертикальне озеленення виконує різноманітні функції: декоративну, захисну, але передусім має велике значення в оздоровленні міського середовища та в покращенні його мікрокліматичних умов. Із кожним роком щільність міської забудови Херсона збільшується, але при цьому межі міста майже не розширюються (Boyko \& Dementeva, 2018). Паралельно також зростає чисельність населення, що веде до необхідності збільшення площі зелених насаджень (Bagatska, 2008). Ще одна проблема великого міста - це збільшення кількості автотранспорту, а разом із тим виникає потреба у площах для їхніх стоянок. Отже, як наслідок, головною проблемою озеленення сьогодні $\epsilon$ нестача вільних площ, на яких можна було б висаджувати дерева та кущі, а також створювати газони або квітники.

Характер забудови міського середовища зумовлює потребу вертикального озеленення території, оскільки несприятливі зміни інсоляції і мікроклімату можливі для $70 \%$ багатоповерхових будинків у Херсоні через недотримання норм і правил містобудування.

Інформація про авторів:

Бойко Тетяна Олексіївна, канд. біол. наук, доцент, кафедра лісового та садово-паркового господарства. Email: t-boiko2015@ukr.net; https://orcid.org/0000-0003-3864-2036

Дементьєва Ольга Іванівна, канд. с.-г. наук, доцент, кафедра лісового та садово-паркового господарства. Email: o-dementeva@ukr.net; https://orcid.org/0000-0001-6112-6772

Котовська Юліанна Станіславівна, асистент, кафедра лісового та садово-паркового господарства. Email: kaf_lis@ukr.nethttps Цитування за ДСтУ: Бойко Т. О., Дементьєва О. І., Котовська Ю. С. Оцінювання біолого-екологічних властивостей деревних ліан в умовах міста Херсон. Науковий вісник НлтУ України. 2019, т. 29, № 5. С. 31-35.

Citation APA: Boiko, T. O., Dementieva, O. I., \& Kotovskaya, Yu. S. (2019). Assessment of Biological and Ecological Properties of Woody Lianas in the Conditions of the City of Kherson. Scientific Bulletin of UNFU, 29(5), 31-35. https://doi.org/10.15421/40290506 
Однією з основних задач вертикального озеленення, в умовах нестачі території, у короткий термін отримати велику зелену площу, а також прикрасити фасади, стіни будівель, огорожі та різного виду опори. Окрім цього, вертикальне озеленення має і суто практичний характер: створення зелених стін, які використовуються для ізоляції окремих ділянок та захисту від перегріву, шуму, пилу (Dementeva et al., 2018).

Мета роботи - встановити еколого-біологічні особливості деревних ліан в умовах міста Херсона.

Матеріали та методи дослідження. Матеріалами для написання роботи стали власні спостереження, виконані впродовж 2015-2019 рр. маршрутно-рекогносцирувальним методом у різних об'єктах озеленення Херсона. Камеральну обробку та гербаризацію зразків витких рослин виконували за загальноприйнятою методикою ботанічних досліджень. Латинські назви рослин наведено за чеклістом (Mosyakin \& Fedoronchuk, 1999), а також за М. А. Кохном (Kokhno, 2005), українські назви - за Визначником (Dobrochaeva et al., 1987) та M. А. Кохном (Kokhno, 2005).

Для об'єктивного оцінення еколого-біологічних властивостей ліан використовували шкали оцінки зимостійкості, посухостійкості, репродуктивної здатності, стійкості деревних інтродуцентів до хвороб та шкідників. Для оцінки зимостійкості ліан в умовах Херсона використано шкалу зимостійкості Е. Л. Вольфа (Vol'f, 1915), інтерпретовану Б. Л. Козловським зі співавторами (Kozlovskij et al., 2000), в якій враховують стан деревних рослин у різні зими, а також вплив обмерзань на подальший розвиток дерев і чагарників. Візуальну оцінку зимостійкості проводили щорічно двічі за сезон: на початку активної вегетації (кінець квітня - початок травня), коли добре помітні зимові пошкодження, й у середині літа, коли можна встановити ступінь відновлення втрачених частин (Boyko et al., 2017). Остаточні висновки про зимостійкість зразка роблять після критичної зими (Kozlovskij et al., 2000). Остаточний бал розраховували як середню величину цієї властивості, виражену в балах (Boiko, Boiko, 2017).

Ще одним показником пристосованості до нових умов, зумовлених посушливим кліматом, пошкоджувальний ефект яких може бути рівним або більш істотним, ніж сукупність несприятливих умов зимового періоду, $є$ посухостійкість. Тому цю властивість деревних рослин у Степовій зоні розглядаємо як одну з найважливіших еколого-біологічних властивостей, що становить адаптаційну характеристику виду. Для оцінки посухостійкості обрали п'ятибальну шкалу А. Н. Корміліцина та І. В. Голубєвої, яка враховує наслідки посухи та потребу у поливі (Kormilicyn \& Golubeva, 1970).

Важливим чинником, який впливає на хід інтродукції, є стійкість до хвороб та шкідників. Пошкодження, які спричиняють ці організми, часто є значною перешкодою для успішної адаптації певного виду. Стійкість деревних інтродуцентів до хвороб та шкідників оцінюють за п'ятибальною шкалою Б. Л. Козловського зі співавторами (Kozlovskij et al., 2000).

Одним 3 показників успішної натуралізації інтродуцентів є здатність до утворення життєздатного насінного потомства в нових умовах. Для оцінки насінної репродукції використано шкалу В. П. Малєєва (Maleev, 1933), однак літерні значення замінено на цифрові (Kozlovskij et al., 2000). У цій шкалі враховують квіт- нення, плодоношення, якість насіння, відсутність або наявність самосіву.

Усі перелічені еколого-біологічні властивості є важливими для виявлення пристосованості у посушливих умовах регіону дослідження. Кожна окрема ознака не дає повної картини про успішність адаптації та натуралізації певного виду. Однак комплекс ознак дає змогу максимально оцінити пристосованість рослини до нових умов середовища. Коефіцієнт адаптації розраховували для кожного виду деревних ліан за Огородніковим (Ogorodnikov, 1993), та виділено п'ять груп рослин, які відрізняються ступенем стійкості та життєздатності, а також перспективами використання у масовій культурі.

Згідно з Козловським та Огородніковим (Kozlovskij et al., 2000; Ogorodnikov, 1993) пристосування деревних рослин до нових екологічних умов виражається сумою балів зимостійкості, посухостійкості, стійкості до хвороб та шкідників та насінної репродуктивності. Ступінь адаптації окремого виду визначається як відношення суми фактичних балів до суми максимально можливих балів (Kozlovskij et al., 2000; Ogorodnikov, 1993):

$$
K_{A}=S_{1} / S \cdot 100, \% \text {, }
$$

де: $K_{A}-$ коефіцієнт адаптації; $S_{1}$ - сума фактичних балів; $S$ - максимальна сума балів. Залежно від величини коефіцієнта адаптації розрізняють п'ять груп рослин (Kozlovskij et al., 2000; Ogorodnikov, 1993), які розрізняються ступенем адаптації, життєздатності та перспективами широкого впровадження в культуру.

Об'єктом дослідження є типові екземпляри, які вступили в репродуктивний вік. Остаточний бал за кожним показником розраховували як середню величину певної властивості, виражену в балах.

Результати дослідження. За результатами наших спостережень на території Херсона, виявлено 31 вид деревних витких рослин. Більшість ліан листопадні, тільки Hedera helix L., Hedera colchika C. Koch, Lonicera giraldii Rehd., Lonicera japonica Thunb. є вічнозеленими рослинами та один вид напіввічнозелених ліан Lonicera $\times$ brownii (Reg.) Carr.

Більшість ліан частіше використовують в озелененні приватних територій, рідше - внутрішньоквартальної забудови і майже не використовують в озелененні територій загального та спеціального призначення. Найчастіше трапляється Parthenocissus quinquefolia (L.) Planch., який висаджують на різних об'єктах озеленення та в приватному секторі. Це пов'язано з такими біологоекологічними особливостями рослини, як швидкий ріст, щільна крона, яскраве забарвлення влітку та восени. Цією ліаною часто заплітають огорожі, високі стіни, де рослина сягає 10-12 м.

Останнім часом у вертикальному озелененні набуває популярності Fallopia baldshuanica (Regel) Holub, який квітне впродовж 2,0-2,5 місяиів, а також Parthenocissus tricuspidata (Siebold \& Zucc.) Planch., який створює щільне покриття вертикальних поверхонь.

За декоративним ефектом виткі деревні рослини Херсона можна розділити на ліани із високодекоративним листям (Hedera helix, Parthenocissus quinquefolia, $P$. tricuspidata тощо), гарноквітучі ліани (Rosa sp., Campsis radicans (L.) Seem., Clematis jackmanii Moore, Lonicera caprifolium L.) (Bagatska, 2008; Dementeva et al., 2018), ліани 3 декоративними плодами - Celastrus orbiculata Thunb., види роду Lonicera, види $з$ декоративним листям і квітками Akebia quinata Dcne., Hydrangea petiolaris (L.). 
Усі деревні ліани, що використовують в озелененні Херсона, $\epsilon$ інтродуцентами. Показниками успішного росту й онтогенезу інтродуцентів у нових для них умовах $€$ їх зимостійкість, тобто властивість рослин витримувати низьку температуру повітря протягом тривалого періоду, посухостійкість - комплекс чинників, пов'язаних 3 аридним кліматом, такі як значне зневоднення та перегрівання, стійкість до шкідників та хвороб, а також здатність до розмноження.
Найбільш зимостійкими ліанами в досліджених умовах виявились Parthenocissus quinquefolia, P. tricuspidata, Lonicera caprifolium, Campsis radicans, a mакож Actinidia kolomikta (Rupr.) Maxim. та Clematis jackmanii (табл.). Менший бал зимостійкості мають Celastrus orbiculata, Lonicera $\times$ brownii, L. periclymenum, Schisandra chinensis, Polygonum baldshuanicum тощо. Найменш зимостійкими в досліджених умовах виявились Akebia quinata, Clematis manschurica Rupr., Fallopia auberti (Henry) Holub та Lonicera $\times$ tellmanniana Mgyar.

Таблиця. Оцінка еколого-біологічних показників дерев'янистих ліан та коефіціснт адаптації до умов міста Херсон

\begin{tabular}{|c|c|c|c|c|c|c|}
\hline $\begin{array}{c}\text { № } \\
\text { 3/ח } \\
\end{array}$ & Назва ліани & \begin{tabular}{|c|} 
Зимос- \\
тійкість
\end{tabular} & $\begin{array}{c}\text { Посухос- } \\
\text { тійкість }\end{array}$ & $\begin{array}{l}\text { Стійкість до хво- } \\
\text { роб та шкідників }\end{array}$ & $\begin{array}{c}\text { Оцінка насінної } \\
\text { репродуктивності }\end{array}$ & $\begin{array}{c}\text { Коефіцієнт } \\
\text { адаптації }\end{array}$ \\
\hline 1 & Actinidia kolomikta (Rupr.) Maxim. & 5 & 3 & 3 & 3 & 70 \\
\hline 2 & Actinidia polygama (Sieb. Et Zucc.) Maxim & 3 & 3 & 3 & 3 & 60 \\
\hline 3 & Actinidia arguta (Siebold \& Zucc.) Planch. ex Miq. & 3 & 3 & 3 & 3 & 60 \\
\hline 4 & Akebia quinata Dcne. & 2 & 2 & 5 & 1 & 50 \\
\hline 5 & Ampelopsis aconitifolia Bge & 5 & 4 & 3 & 4 & 75 \\
\hline 6 & Campsis radicans (L.) Seem. & 5 & 4 & 5 & 2 & 80 \\
\hline 7 & Celastrus scandens L. & 4 & 4 & 4 & 2 & 70 \\
\hline 8 & Celastrus orbiculata Thunb. & 4 & 4 & 4 & 3 & 75 \\
\hline 9 & Clematis mandschurica Rupr. & 2 & 3 & 4 & 4 & 70 \\
\hline 10 & Clematis jackmanii Moore & 5 & 3 & 4 & 3 & 75 \\
\hline 11 & Clematis glauca Willd. & 3 & 3 & 4 & 4 & 70 \\
\hline 12 & $\begin{array}{l}\text { Fallopia baldshuanica (Regel) Holub } \approx \text { Polygonum } \\
\text { baldshuanicum Regel }\end{array}$ & 4 & 5 & 3 & 4 & 80 \\
\hline 13 & Fallopia aubertii (Henry) Holub & 2 & 4 & 4 & 5 & 85 \\
\hline 14 & Hedera helix $\mathrm{L}$. & 4 & 4 & 5 & 3 & 80 \\
\hline 15 & Hedera colchika C. Koch & 4 & 3 & 4 & 3 & 70 \\
\hline 16 & Hydrangea petiolaris (L.) & 4 & 3 & 4 & 1 & 55 \\
\hline 17 & Lonicera periclymenum $\mathrm{L}$. & 4 & 3 & 5 & 3 & 65 \\
\hline 18 & Lonicera $\times$ brownii (Reg.) Carr. & 3 & 3 & 5 & 3 & 70 \\
\hline 19 & Lonicera caprifolium L. & 5 & 4 & 3 & 4 & 85 \\
\hline 20 & Lonicera giraldii Rehd. & 5 & 4 & 4 & 3 & 80 \\
\hline 21 & Lonicera japonica Thunb. & 4 & 3 & 5 & 3 & 70 \\
\hline 22 & Lonicera $\times$ tellmanniana Mgyar. & 2 & 3 & 3 & 3 & 55 \\
\hline 23 & Menispermum canadense L. & 3 & 3 & 5 & 4 & 75 \\
\hline 24 & Parthenocissus quinquefolia (L.) Planch. & 5 & 4 & 4 & 4 & 85 \\
\hline 25 & Parthenocissus tricuspidata (Siebold \& Zucc.) Planch. & 5 & 4 & 4 & 4 & 85 \\
\hline 26 & Periploca graeca $\mathrm{L}$. & 4 & 4 & 4 & 4 & 80 \\
\hline 27 & Rosa sp. & 5 & 3 & 2 & 1 & 55 \\
\hline 28 & Schisandra chinensis (Turcz.) Baill. & 5 & 2 & 5 & 3 & 75 \\
\hline 29 & Vitis amurensis Rupr. & 4 & 3 & 2 & 4 & 65 \\
\hline 30 & Vitis vinifera $\mathrm{L}$. & 4 & 3 & 1 & 1 & 45 \\
\hline 31 & Wisteria sinensis (Sims) Sweet & 5 & 5 & 5 & 3 & 85 \\
\hline
\end{tabular}

Лімітуючим чинником у поширенні інтродукованих рослин може стати режим зволоження. За нашими спостереженнями, найвищий бал посухостійкості присвоєний тільки Fallopia baldshuanica та Wisteria sinensis. Інші види - менш посухостійкі. Celastrus orbiculatus, Lonicera caprifolium, Lonicera periclymenum L., Parthenocissus quinquefolia, Campsis radicans, Periploca gra$e c a$ L. мають за цією ознакою 4 бали. Ці рослини можуть рости і розвиватись без поливу, однак у разі тривалих посух рослини скидають листя, бруньки та насіння, але добре відновлюються на наступний рік. Інші ліани середньопосухостійкі та слабкопосухостійкі.

Розмноження насінням свідчить про високий ступінь адаптації рослин-інтродуцентів в дослідженому регіоні. В умовах Херсона самосів рясно утворюють Wisteria sinensis, Periploca graeca, Ampelopsis aconitifolia, Clematis manschurica, C. glauka Willd. Інші виткі рослини частіше розмножуються вегетативним шляхом.

За результатами аналізу стійкості до хвороб та шкідників з'ясовано, що найвищий бал за шкалою Б. Л. Козловського зі співавторами присвоєний Celastrus scan- dens, Lonicera periclymenum, L. brownii, L. japonica, Menispermum canadense L., Schisandra chinensis (Turcz.) Baill., Wisteria sinensis, у яких не було виявлено ознак пошкоджень. За літературними джерелами ці види також визначають як стійкі. Найстійкіші до інших чинників деревні ліани можуть пошкоджуватись або хворіти. Так, Parthenocissus quinquefolia та $P$. tricuspidata, які відрізняються високою екологічною пластичністю, у спекотний і посушливий періоди уражаються павутинним кліщем та попелицею, а також на їх листках було виявлено ураження борошнистою росою та антракнозом. Борошниста роса також часто уражає представників роду Actinidia, Fallopia baldshuanica, Rosa sp., молодi пагони Lonicera caprifolium. П'ятнистості листя з'являються у Akebia quinata, Hydrangea petiolaris, іржею уражається Rosa sp. Різноманітні кліщі уражають види роду Clematis, Ampelopsis aconitifolia, Hedera helix, H. colchika, Hydrangea petiolaris, Vitis vinifera. Попелицею уражаються листя Campsis radicans, Hedera helix, Hydrangea petiolaris, Lonicera caprifolium, Periploca graeca. Vitis amurensis та $V$. vinifera хворіють мільдью та 
уражаються філоксерою. Vitis vinifera також уражається антракнозом, сірою гнилизною та чорною плямистістю.

За літературними джерелами Clematis jackmanii часто уражається вілтом, борошнистою росою, іржею тощо. Однак в умовах Херсона ми виявили тільки ураження борошнистою росою. Незважаючи на найнижчий показник стійкості до хвороб та шкідників, виноград культурний (1 бал) та роза витка (1 бал) досить часто трапляються в Херсоні. Господарське значення першого та висока декоративність другого виду зумовило їх значне поширення та використання у вертикальному озелененні.

За результатами визначення коефіцієнту адаптації деревних ліан, що використовуються в озелененні Херсона, виявлено, що найвищий коефіцієнт адаптації (9575 балів) мають Ampelopsis aconitifolia, Campsis radicans, Celastrus orbiculata, Clematis jackmanii, Parthenocissus quinquefolia, P. tricuspidata, Lonicera caprifolium, L. giraldii, Fallopia baldshuanica, F. auberti, Menispermum canadense, Wisteria sinensis, Periploca graeca. Представлені види виявились найбільш адаптованими до досліджених умов, достатньо посухостійкі та зимостійкі, майже не пошкоджуються шкідниками та хворобами, відповідно, є перспективними для широкого впровадження в озеленення міста Херсон (таблиця).

Обмежено перспективними видами для вертикального озеленення Херсона є види з коефіцієнтом адаптації 74-60 балів: Actinidia kolomikta, Hedera colchika, Lonicera $\times$ brownii, L. periclymenum, L. japonica, Celastrus scandens, Clematis manschurica, C. glauca, Vitis amurensis (див. таблицю). Ці види також можливо використовувати для озеленення Херсона, однак через свої біологічні особливості потребують догляду за ними. В основному ці рослини потребують ретельного обрізання, захисту від вітру та укриття на зимовий період. Рослини $з$ низьким балом насіннєвої репродукції добре розмножуються вегетативним шляхом.

Celastrus scandens віднесено до цієї категорії. Однак вид достатньо декоративний та перспективний для озеленення бетонних стін та огорож. У деякі зими молоді рослини підмерзали, однак швидко відновлювались наступного вегетаційного сезону. Дорослі рослини не потребують укриття на зиму. За літературними джерелами деревозгубець розмножується насінням, однак самосіву не було виявлено, хоча насіння в лабораторних умовах проростали. Можливо, це пов'язано з невеликою кількістю обстежених екземплярів. Цей вид може активно впроваджуватись в озеленення Херсона, однак його не слід висаджувати поблизу цінних порід дерев, оскільки він здатен пригнітити рослину, яку використовує як опору.

Малоперспективними видами ліан, згідно з проведеним дослідженням, є види 3 коефіцієнтом адаптації 4559: Akebia quinata, Hydrangea petiolaris, Lonicera tellmanniana, Rosa sp., Vitis vinifera L. Усі ці види виявлено у придомових ділянках та приватному озелененні, тому їм був забезпечений догляд. Однак, незважаючи на високу декоративність, ці деревні ліани мало придатні для широкого впровадження.

Висновки. Виконанню робіт з озеленення в Херсоні потрібно надати цілеспрямованого науково обгрунтованого характеру, що можливо на основі дослідження видового то формового різноманіття деревних рослин, їх біоекологічних та декоративних особливостей, а також використання досвіду їх культивування в цьому регіоні.

На території Херсона росте 31 вид деревних ліан. Дослідження закономірностей адаптації інтродукованих деревних ліан до нових умов навколишнього середовища дає змогу визначити шляхи збагачення видового складу об'єктів різного функціонального призначення цінними та високодекоративними видами.

\section{Перелік використаних джерел}

Bagatska, O. M. (2008). Features of growth and development of introductive types of woody lianas and prospect of their use in planting of greenery of Kyiv city. Kyiv: National Agrarian University, 22 p. [In Ukrainian].

Boiko, T. O., \& Boiko, P. M. (2017). Evaluation Introduction Albizia julibrissin Durazz in Kherson City. (Ser. Biology). In Traektoria nauki: International Electronic Scientific Journal, 3(1), (pp. 31-37). https://doi.org/10.22178/pos.18-3

Boyko, T. O., \& Dementeva, O. I. (2018). Ecological bases of creation of green plantations in the territories of general educational institutions of Kherson city. Tavrian Scientific Bulletin, 100(1), 276-282.

Boyko, T. O., Boyko, P. M., \& Sichna, Yu. M. (2017). Winter hardiness and frost resistance of Albizia julibrissin Durazz in conditions of Kherson. Plant introduction, 4(76), 63-68. [In Ukrainian].

Dementeva, O. I., Ostroverh, A., \& Vech, B. (2018). Assortment of lianas in landscaping of the Kherson city. Materials of the scientific and practical internet conference of teachers, young scientists and students, (pp. 176-178), Kherson. [In Ukrainian].

Determinant. (1987). Determinant of higher plants of Ukraine. Kyiv: Scientific thought. [In Russian].

Kormilicyn, A. N., \& Golubeva, I. V. (1970). Woody plants of the State Arboretum of Nikitsky Botanical Garden. Catalog dendrological collections of the Arboretum of Nikitsky botanical garden. Jalta, Tavrida, $90 \mathrm{p}$.

Koxno, M. A., Trofymenko, N. M., \& Parxomenko, L. (2005). Dendroflora of Ukraine. Wild and cultivated trees and bushes. (Part 2). Kyiv: Fitosociocentr, 716 p. [In Ukrainian].

Kozlovskij, B. L., et al. (2000). Flowering woody plants of the Botanical Garden of the Rostov University (ecology, biology, geography). Rostov-on-Don: Starye russkie, 144 p. [In Russian].

Maleev, V. P. (1933). Theoretical Foundations of acclimatization. Leningrad: Publishing house of agricultural and collective farm cooperative, lit., 168 p. [In Russian].

Mosyakin, S. L., \& Fedoronchuk, M. N. (1999). Vascular plants of Ukraine. A nomenclatural checklist. Kyiv, 346 p.

Ogorodnikov, A. Ya. (1993). Methods of visual assessment of bioecological properties of woody plants in the settlements of the steppe zone. Itogi introduktsii rasteniy, (pp. 50-58). Rostov-on-Don: RGU. [In Russian].

Volf, Je. L. (1915). Ornamental shrubs and trees for gardens and parks. Saint-Petersburg: Publishing house Devriena, 462 p. [In Russian].

T. O. Boiko, O. I. Dementieva, Yu. S. Kotovska Kherson State Agricultural University, Kherson, Ukraine

\section{ASSESSMENT OF BIOLOGICAL AND ECOLOGICAL PROPERTIES OF WOODY LIANAS IN THE CONDITIONS OF THE CITY OF KHERSON}

According to the results of our research in the city of Kherson, 31 species of woody lianas were found. Most lianas are deciduous, only one species Hedera taurica Carrière is evergreen and one species of semi-evergreen lianas is Lonicera periclymenum 
L. All woody lianas used in landscaping of Kherson are introduced species. Indicators of the successful growth and ontogenesis of introduced species in new conditions for them are their winter hardiness, drought resistance, resistance to pests and diseases, as well as the ability to reproduce. Each property is calculated according to the appropriate scale. The average values for the properties are calculated and expressed in points for each species. Parthenocissus quinquefolia (L.) Planch., P. tricuspidata (Siebold \& Zucc.) Planch., Lonicera caprifolium L., Campsis radicans (L.) Seem., Actinidia kolomikta (Rupr.) Maxim. Clematis jackmanii Moore turned out to be the most winter-hardy lianas in the studied conditions. We consider drought resistance of woody plants in the steppe zone to be one of the most important ecological and biological properties; it is an adaptation characteristic of the species. The fivepoint scale chosen takes into account the effects of drought and the need for watering. The highest score of drought tolerance is presented only by Fallopia baldshuanica (Regel) Holub and Wisteria sinensis (Sims) Sweet. Other species are less drought-resistant. Resistance to diseases and pests is an important factor influencing the course of introduction. It was found that the most resistant are Celastrus scandens L., Lonicera periclymenum L., L. brownii (Reg.) Carr., L. japonica Thunb., Menispermum canadense L., Schisandra chinensis (Turcz.) Baill., Wisteria sinensis (Sims) Sweet. The ability to form viable seeds and self-seeding in new condition also indicates successful naturalization. Wisteria sinensis, Periploca graeca L., Ampelopsis aconitifolia Bge, Clematis manschurica Rupr., C. glauka Willd. abundantly form self-seeding. Determination of adaptation coefficient of woody lianas showed that the most suitable for the study conditions are as follows: Ampelopsis aconitifolia, Campsis radicans, Celastrus orbiculata Thunb., Clematis jackmanii, Parthenocissus quinquefolia, P. tricuspidata, Lonicera caprifolium, L. giraldii Rehd., Fallopia baldshuanica (Regel) Holub, F. auberti (Henry) Holub, Menispermum canadense, Wisteria sinensis, Periploca graeca. Other species are of limited promise for vertical gardening of the city of Kherson, but their use is possible with careful selection of the planting site and providing proper care for them.

Keywords: lianas; vertical gardening; winter hardiness; drought resistance; adaptation. 